\title{
Theories of Conflict and Conflict Resolution
}

\author{
Ningxin Li \\ Nova Southeastern University \\ USA
}

\section{Introduction}

This paper presents a focused and in-depth discussion on the theories of Basic Human Needs Theory, Marxism, and Post-modernity, which analyze social structures and social developing processes. Different theories of each expert are analyzed from the perspectives of their definitions and functions. The ideas of experts are essential to understand different cultures, societies, and the human need for balance. Furthermore, the strengths and weaknesses of different theories will be clarified, as will the social problems and potential consequences of implementing different theories. Exploring these theories through different lenses, such as ethics and power, help to illustrate the applications of different theories in studying peace and conflict resolution.

Keywords: The Theory of Karl Marx, Human Needs Theory, The Theory of Wright Mills, The Theory of Antonio Cramsci, The Theory of Jean-Francois Lyotard, The Theory of Anthony Giddens

\section{The Theory of Karl Marx}

Karl Marx (1818 -1883) was a philosopher and sociologist. His theory, Marxism, analyzes class relations and critiques the development of capitalism. He indicates the conflicts between the ruling classes and working classes (Peter, 2002). Marx clearly sees that capitalists form a ruling class. In Marx's theory, bureaucracy rarely creates new wealth by itself, but by controlling and distributing (Peter, 2002). For Marx, "class antagonisms under capitalism, owing in part to its instability and crisis-prone nature, would eventuate the working-class' development of class consciousness" (Lemert, 2004). Marx implied that the legal system is applied by rulers to enhance their authority. He observed that labor-market relations were especially strained in our society and how they influenced on how the industry operated (Schellenberg, 1996), as well as how all the different classes in a society were impacted and challenged by the ruling class. Marxism creates a system with shared equality in which an emphasis on human rights is important. According to Marxian theory, class conflict arises in capitalist societies due to contradictions between the material interests of the oppressed employees (Lemert, 2004).

Marxism encourages free market competition. The process of bureaucratization in the state administration itself is a parallel phenomenon of democracy (Lemert, 2004). His theory implies the mutual relations between the producers and the labor itself. It indicates ideas of the root problems of social disruption and class conflicts. Also, Marx suggested that capitalists invest more in improving new technologies than labor. What is good for the ruling class should be good for the whole of the society with which the ruling class identifies itself (Lemert, 2004).

Marxist theory provides the key to human observation in analyzing the internal structure of society from the standpoint of dialectical and historical materialism. Marxism mentioned how the society would look under the control of capitalism and illustrated the consequences of continuing tyranny (Peter, 2002). Marx's analysis of capitalism further underlines its weaknesses. My criticism of Marxism is that bureaucracies provide the possibility for the government to function effectively and guide organizations and public companies in an orderly way. Although bureaucracy is not perfect to maintain a society, it helps maintain social order. Instead of feeling discouraged, many people were willing to contribute their strengths and ideas to the development of the society. Marx recognized that human relationships had become "rationalized" according to a purely economic logic (Peter, 2002). Also, Marxism encourages people to protect their rights and encourages workers to achieve their goals. His theory helps correct political decisions and creates a harmonious political and ecological environment. Whether a person's value is small or big, the evaluation varies among each individual. The most important thing is to participate in the production and practical activities of the society and its developing process.

\section{The Theory of Max Weber}

Max Weber (1864-1920), a German sociologist, described a theory known as Weberian bureaucracy. Bureaucracy is the administrative system governing any large institution. 
Weber analyzed the causes of bureaucracy in terms of cultural roots. Weber described an ideal type of bureaucracy and considered it to be a rational domination (Gane, 2012). Compared to Marx's theory, Weber indicated that bureaucracy was the most effective way to run an administration, more than traditional structures (Gane, 2012). Weber expressed ideas from social, cultural, and personal perspectives and pointed out that any of organization is based on some form of authority, which can eliminate chaos and give order to the society.

From an economic point of view, the development of the commodity economy has provided a strong impetus to the emergence of bureaucratic organizations (Lemert, 2004). Weber's theory provides implications for the current society. For example, social actions that directly determine the class situation of the worker and the entrepreneur are: the labor market, the commodities market, and capitalistic enterprise (Lemert, 2004). "Class" is an unambiguously economic interest and only the interests of those responsible for managing the market maintain the class situation (Lemert, 2004). Weber indicated modern bureaucracy, which includes concentration of the means of administration and its impersonality (Gane, 2012). He believed that administrative regulations help allocate tasks to different fields. Weber's theory helps in showing how to make the social system more efficient. In addition, Weber viewed a society with its rationalization. Rationalization includes changes in ethics or culture, one of the fundamental elements of the spirit of modern capitalism and of all modern culture (Lemert, 2004, p. 103).

Critical responses to Weber: My question to Weber's historical analysis is that sometimes a decision itself is more important than the efficiency of distributing works. It is difficult to predict the changes of this world; sometimes conflicts are inevitable and hard to control to develop a bureaucratic line. Officials can pass the buck to others and delay the working procedures to avoid responsibility, or when people make decisions too slowly, it can also result in negative consequences in certain circumstances. There should be a flexible way to manage the risks of changes. The inspiration of this theory is that by decentralizing power people need to pay more attention to creating rational thoughts, respect knowledge and talents, and take advantage of the superiority of bureaucracy.

\section{The Theory of Human Needs Theory}

The Basic Human Needs Theory describes human intentions and behaviors, as well as analyzing resolutions for conflict. John Burton presented a list of needs including that human beings need to have a sense of security, and people require both recognition and valued relationships. Also, individuals want control over their surroundings to make sure their needs are satisfied (Burton, 1990). In addition, human needs include having a sense of security and recognition. There are fundamental needs that all human beings have (Park, 2010). People have basic needs, such as safety, belongingness of love, and self-actualization (Rubenstein, 2001). They also have a need to encourage others, promote justice, and have the belongingness of love and a need to care for others. These positive human needs can not only benefit ourselves, but also strengthen other people's needs and increase satisfactions. By learning the Human Needs Theory, a growing problem can be solved deliberately, and it will help people distinguish different causes of conflicts (Burton, 1979).

Abraham Harold Maslow (1908-1970) designed Maslow's hierarchy of needs, which reflects to some extent human behavior and mental activity (Maslow, 1987). He explored human incentives and behaviors. Also, he stated that human motivation is based on people seeking different needs. For example, he indicated that human needs can be ranked in order of importance and hierarchy, from basic needs, such as food and housing, to complexes needs, such as self-actualization (Maslow, 1987). In addition, people have the need of friendship; everyone needs to be in a harmonious relationship among colleagues and friends. Everyone has hopes for love and the love of others (Rubenstein, 2001). Moreover, Maslow's hierarchy of needs theory points out that in different periods of time people may have different needs to focus on; they have dominant needs, as well as other basic needs. Human behaviors are impacted by the outside environment, such as encountering wars and conflicts. The problem for this theory is that people's needs may change in different periods and circumstances. Individuals might not meet all their needs at the same time. It is difficult to say how and when our needs can be achieved, especially under social chaos.

\section{The Theory of Wright Mills}

Wright Mills (1916-1962) was a social theorist. He asserted that social science was neither pure science nor pure humanities (Lemert, 2004). He found a way to connect individual experiences and societal relationships. As a student of Max Weber, Wright Mills' theory indicated that rationalization is the practical application of knowledge to achieve a desired end (Lemert, 2004). 
Mills believed that the social bureaucratization was unevenly distributed. Bureaucratization shaped the political and economic elites, which threatened the lower classes to accept freedom and democracy (John, 2003). Also, the theory of Wright Mills gives ideas on general social structure and the historical development of bureaucracy, which implies that sociological imagination was becoming the major common denominator of our cultural life.

Mills suggested that people were at the 'Modern Age', which was decades before post modernity became prominent in sociology (John, 2003). He analyzed the sociocultural systems and gave thought on the Sociological Imagination in studying human condition (Lemert, 2004). His ideology, Sociological Imagination helps people distinguish between personal and public issues. It also implies that the concentration of wealth and power can cause imbalance with unequal opportunities for people to meet their needs (Mills, 1956). For example, individuals may have both personal and social issues which are connected in their everyday life. When there are many people who are poor and living under repression, it might impact the overall economic and social development. By understanding the sociological imagination theory, it helps people understand how to adjust themselves in the society and avoid isolation from the disconnect benefiting the society.

\section{The Theory of Antonio Cramsci}

Antonio Gramsci (1929-1936) was an Italian Marxist philosopher and politician. Gramsci indicated that cultural hegemony was ruled by a class who manipulated the culture of that society, such as the beliefs and values (Adamson, 2014). His thoughts would influence later social and cultural theory (Lemert, 2004). Gramsci's theory, cultural hegemony describes the ruling capitalist class which maintains power in capitalist societies. Gramsci agreed with Marx's theory that the superstructure maintains the classes' relationships. This theory is a tool for exploring the dynamic relationships between culture, politics, and economy (Adamson, 2014). Gramsci also encouraged the development of a new culture, which advocated for the equal rights of people. His "cultural hegemony" theory indicates that the mass media has become one of the important tools for capturing ideological leadership and helps to explore the relationship between hegemony and the world order (Adamson, 2014). It enlightens the thought of cultural leadership and its construction in the society, which raises the moral culture of the public and helps people adapt to the requirements of the development of productive forces.

In addition, Gramsci had a sense of building civic capacities to think differently to challenge assumptions and articulate new ideas (Lemert, 2004). "Political society" can be divided into the police, the army, and the legal system (Forgacs, 2000). Governments should uphold a system of public order and justice (Schellenberg, 1996). However, Gramsci indicated that the capitalists use state apparatus and force political power to the society (Schellenberg, 1996). His theory provides inspiration for the ruler of how to avoid conflicts and manage affairs fairly. However, this theory lacks explanation on how to allow the capitalist state to have control over residence, to have self-control instead of taking advantage of the system.

\section{The Theory of Jean-Francois Lyotard}

Jean-François Lyotard (1924-1998) was a French philosopher, best known for his highly influential formulation of postmodernism in The Postmodern Condition (Lyotard, 2003). His thoughts can be applied to many areas, such as politics. It is Lyotard's view that certain technical and technological advancements have taken place since the Second World War (Lemert, 2004). Postmodern condition describes the economic or cultural state of society that is said to exist after modernity (Lyotard, 2003). In contemporary society and culture, postmodern culture implies that the upsurge of technology would have an impact on the status of knowledge. Also, postmodernism requires people to understand scientific truth as a culturally specific achievement dependent on social conditions for its production and reproduction (Lemert, 2004). The theory of Jean-Francois Lyotard reminds people to pay attention to the existence of social and individual differences, while recognizing the shortcomings of the holistic thinking paradigm. Moreover, his theory provides a unique perspective for the innovation of moral education. People need to pay attention to the diversity and heterogeneity of moral values. Additionally, building a democratic and equal relationship between people is important to maintain a harmonious environment.

\section{The Theory of Anthony Giddens}

Sociology is a broad and diverse subject, which inhibits a satisfactory analysis of modern institutions (Giddens, 1990). Anthony Giddens' refers to the current society as a continuation of the modern ideology. His theory provides approaches in people's social life. He grasped the distinctive culture of late modernity and claimed that it is necessary to introduce a new concept of disembodying (Giddens, 1982). 
Also, Giddens argued that Marx's anticipations of an order in which class domination would be replaced by a rational order, in which the free development is the condition. Anthony Giddens concentrated on a contrast between traditional (pre-modern) culture and post-traditional (modern) culture (Loyal, 2003). People were influenced by global change and created new ways of communication and technology. He argued that modernity opens new opportunities for humans to achieve their goals and he saw the current situation as a high modernity. Any attempt to capture the experience of modernity must derive from the dialectics of space and time, as expressed in the time-space constitution of modern institution (Lemert, 2004, p. 478).

Modernity does not mean that people always live in a safe and humane world. Confusion and doubt stimulate uncertainty. People will have different choices for maintaining a sustainable social system and understand the history to realize that modernity cannot only rely on traditional rules, people can consider things flexibly along with making processes of rationalization and motivation (Loyal, 2003). Furthermore, modernity is a risk culture, Giddens placed the risk in his investigation of the modern society and used his theory to reflect modernity (Loyal, 2003). The mix of risks and opportunities is complex in many situations. This theory gives inspiration that building trust and managing risks are important. People need to seek different opportunities, avoid potential conflicts, and pursue peace (Loyal, 2003).

\section{The Theory of Cornel West}

American philosopher Cornel West described that the new cultural politics included notions of modernity, margins, and difference (Lemert, 2004). West stated that Marxist theory is insufficient, because Marxist Theory did not fully give explanations on how cultural factors could impact the changing society. He saw a culture with depoliticized policy to empower people to have rights to react to the society (West, 1999). He indicated that the new cultural politics have three basic challenges, such as intellectual, existential and political. His ideas help people critically understand the practical world (Lemert, 2004). For example, he indicated that Jewish people, white people, and gentiles are alike in their positive capacities, such as human sympathy, service to others, intelligence, and beauty (Lemert, 2004).

West disclosed the structures of power and analyzed problems that were rooted in the past. He addressed the struggles of the African American working class (Keith, 2008). West believed that "the best examples of African American humanism are the spirituals, the blues, gospel, and jazz" (Keith, 2008). However, his thoughts include how the black community was isolated by itself from the white community and he stated that the same rules of self-destructive isolation and pandering to the lowest common denominator can apply to any group between black and white people (West, 1999). By learning this theory, it helps to understand that people should respect cultural dynamics, be open-minded, and update their knowledge in understanding different personal identities. West's thoughts help people realize how to promote political and emotional reconciliation, protect rights of different classes and races, respond to civil voices, and recover their political responsibility.

\section{Conclusion}

Marxist theory revealed the principle of the evolution and development of human society. While, Weber believed in the importance of cultural influences for understanding capitalism, and the Human Needs Theory helped people understand the process of human growth. In Postmodern theory, it considered the change of new life and gave ideas on pursuing justice. By comparing and applying different knowledge of theories respectively, it helps in studying political systems, bureaucratic structures, as well as rationally analyzing human affairs. Also, it is important to gain trust between people and encourage them to fulfill justice in the society. All these theories can help people understand the importance of protecting human rights and developing a sustainable society. By finding the meanings of different theories, it becomes apparent that people don't have control over time, however, they can learn from history, find alternative ways, and avoid conflicts to improve the society.

\section{References}

Adamson, L., Walter. (2014). Hegemony and Revolution: Antonio Gramsci's Political and Cultural Theory. Vermont: Echo Point Book \& Media.

Burton, J. (1990). Conflict: Resolution and Prevention. NY: St. Martin's Press.

Burton, J. (1979). Deviance Terrorism \& War: The process of solving unsolved social and political problems.

Australia: Australian National University Press. Retrieved from: https://openresearch. 
Giddens, A. (1982). Classes, Power and Conflict: Classical and Contemporary Debates. LA: University of California Press.

Gane, N. (2012). Max Weber and Contemporary Capitalism. UK: Palgrave Macmillan.

John, D, Brewer. (2003). C. Wright Mills and the ending of violence. NY: Palgrave Macmillan.

Keith, G. (2008). Composition and Cornel West. Illinois: Southern Illinois University Press.

Laureen Park "Opening the black box: reconsidering needs theory through psychoanalysis and critical theory" International Journal of Peace Studies. 15.1 (Spring-Summer 2010) p1.

Lemert Charles. (2004). Social Theory: The Multicultural and Classic Readings. Colorado: West view Press.

Lyotard, J., F. (2003). Postmodern Fables. MN: University of Minnesota Press.

Loyal, S. (2003). The Sociology of Anthony Giddens. London: Pluto Press.

Mills, W. (1956). The power Elite. NY: Oxford University Press.

Maslow, A., H. (1987). Motivation and Personality. New York, NY: Harper \& Row.

Peter, W. (2002). Marx and Marxism. London: Routledge.

Rubenstein, R. (2001). Basic Human Needs: The Next Steps in Theory Development. International Journal of Peace Studies. Retrieved from: http://www.gmu.edu/programs/icar/ijps/vol6_1/Rubenstein.htm

Schellenberg, A., James. (1996). Conflict Resolution: Theory, Research, and Practice. NY: State University of New York.

West, C. (1999). The Cornel West Reader. NY: Basic Caritas Books.

Forgacs, D. (2000). The Antonio Gramsci Reader. NY: New York University Press. 